Paedagogia Christiana

I/29 (2012) - ISSN 1505-6872

Katarzyna Olbrycht ${ }^{*}$

Cieszyn

\title{
Wychowanie do wartości - w centrum aksjologicznych dylematów współczesnej edukacji
}

\section{Jak rozumieć związek edukacji z wychowaniem do wartości?}

Edukacja, jedno z podstawowych pojęć pedagogicznych, jest dziś interpretowana na wiele sposobów. W literaturze przedmiotu możemy znaleźć pogłębione analizy najważniejszych współczesnych teorii i koncepcji edukacji, ideologii edukacyjnych, systemów edukacji, prowadzone głównie na gruncie pedagogiki, socjologii i filozofii ${ }^{1}$. Jednym z kluczowych problemów tych analiz są funkcje edukacji we współczesnym świecie, w określonych sytuacjach cywilizacyjnych, tradycjach, kulturach, politykach narodowych. Funkcje te wiążą się z wyznaczanymi edukacji celami, źródłami i sposobami ich uzasadniania, co wymaga poznania przyjmowanych w danej koncepcji edukacji podstaw aksjologicznych. Taki sposób patrzenia na edukację wydaje się jednak odległy od współczesnej praktyki edukacyjnej, która zajmuje się przede wszystkim szczegółowymi treściami, metodami, formami

* Prof. zw. dr hab. Katarzyna Olbrycht - kierownik Zakładu Edukacji Kulturalnej w Instytucie Nauk o Edukacji Wydziału Etnologii i Nauk o Edukacji w Cieszynie.

${ }^{1}$ Por. np. bardzo interesującą socjologiczną analizę współczesnych ujęć edukacji, ich kontekstów i uwarunkowań, zawartą w tekście: Socjologia edukacji Rob Moore, w: B. Śliwerski (red.), Pedagogika edukacji, polityki oświatowej i badań naukowych, t. 2, Gdańsk 2006; czy analizy modernistycznego i postmodernistycznego podejścia do edukacji prowadzone przez Z. Melosika - m.in. Kultura, akademia i edukacja-modernistyczno/postmodernistyczne interpretacje, „Przegląd Pedagogiczny” 1 (2011). 
i środkami, nie wnikając ani w założenia, ani w uzasadnienia przyjmowanych rozwiązań.

W praktyce pedagogicznej można dziś dostrzec kilka zasadniczych tendencji w interpretowaniu edukacji. Są to: najogólniej rozumiany całokształt oddziaływań kształcących i wychowawczych, w węższym zakresie - działania oświatowe łączone głównie z systemami szkolnymi, bądź wreszcie - procesy kształcenia kompetencji (wiedzy i umiejętności) oraz postaw uznanych społecznie za pożądane. Kształcenie pożądanych społecznie kompetencji i postaw, określane edukacją, funkcjonuje najczęściej w połączeniu z określeniami dodawanymi ze względu na różne kryteria, między innymi ze względu na etap, na którym jest realizowane (np. edukacja przedszkolna, wczesnoszkolna), charakter (np. edukacja formalna i nieformalna), przedmiot (np. edukacja ekologiczna, językowa, techniczna, regionalna, europejska) czy wreszcie dziedzinę życia, do której edukacja ma przygotowywać (określana jako „edukacja do...”). Treść edukacji w ostatnim z wyodrębnionych znaczeń (kształcenie pożądanych społecznie kompetencji, cech, postaw) uwarunkowana jest $\mathrm{z}$ natury rzeczy wielorakimi czynnikami i podlega stosunkowo częstym zmianom. Można postawić ostrożną tezę, iż pojęcie edukacji zaczęło być stosowane w miejsce używanego wcześniej pojęcia wychowanie, szczególnie gdy wychowanie odnoszone było do określonej sfery rzeczywistości (np. umysłowe, estetyczne, patriotyczne, obywatelskie). Przyczyny tej zmiany wymagałyby dłuższej analizy. W tym miejscu ograniczmy się do tezy, iż zmiana ta wiązała się, i w pewnym stopniu wiąże się do dziś $\mathrm{z}$ bardziej neutralnym teleologicznie i aksjologicznie wydźwiękiem pojęcia edukacja. Obejmuje ono zarówno tradycyjnie wąsko rozumiane wychowanie, jak nauczanie. Posługiwanie się nim daje więc możliwość elastycznego akcentowania raczej wymiaru instrumentalnego, sprawnościowego - a więc dydaktycznego, bądź raczej (choć rzadziej) kierunkowego - wychowawczego. Znamiennym dla tendencji unikania wyraźniejszego określenia zakresu działania i odpowiedzialności edukacyjnej było wprowadzenie do języka reformy szkolnej pojęcia edukator, które miało stworzyć niejako nową rolę promotora reformy, a równocześnie zastąpić teoretycznie węższe pojęcie wychowawca, kojarzące się bardziej z kształceniem kierunkowego wymiaru osobowości (trudniejszego do nazwania i uzasadnienia), a także w jakimś stopniu - pojęcie nauczyciel. Ostrożność i niechęć do posługiwania się pojęciami wychowanie i wychowawca ma wyraźne źródła aksjologiczne. Współczesna kultura zdominowana jest myśleniem w duchu pragmatyzmu i postmodernizmu, które to odrzucają mocniejszy niż czysto subiektywny status wartości bądź w ogóle negują sens posługiwania się pojęciem wartości. Tym samym sceptycznie traktują wychowanie jako działanie programowo zorientowane na realizację określonych ideałów wychowania, uznając 
je samo w sobie za zagrażające wolności jednostki. Dochodzi w ten sposób do szczególnej antynomii. Domagając się uwolnienia edukacji od wartości i ideałów, milcząco zakłada się edukowanie do respektowania na przykład praw człowieka bez poddawania ich społecznej dyskusji czy też ich negocjowania jako celu edukacji. Trudność jednoznacznego określania zakresu wychowania i roli wychowawcy wzrasta szczególnie w sytuacjach społecznych sporów ideowych i ideologicznych, co ma miejsce także w Polsce. Niestety, ani w środowiskach oświatowych i wychowawczych, ani w społecznych debatach problem niejasnego sensu i zakresu wychowania nie znajduje odpowiedniego oddźwięku. W praktyce społecznej obserwuje się raczej reakcje unikowe, uruchamiające w konsekwencji programy ukryte, wyznaczane przez dominujące $\mathrm{w}$ danym momencie mechanizmy socjalizacyjne.

$\mathrm{W}$ podjętych tu rozważaniach edukacja będzie rozumiana w duchu tradycji greckiej paidei - a więc szeroko, jako całościowe wychowanie człowieka, obejmujące zdobywanie wiedzy, sprawności i postaw, pożądanych w doskonaleniu człowieczeństwa, w służbie jednostce i społeczeństwu, wyraźnie określające wartości, na jakie powinno być zorientowane wychowanie - edukacja człowieka. Wartości te wynikają z interpretowania człowieczeństwa i jego doskonalenia w świetle antropologii personalistycznej, z podkreśleniem perspektywy personalizmu chrześcijańskiego jako podstawy edukacji religijnej związanej z wychowaniem chrześcijańskim.

Wychowanie, niezależnie od deklarowanych założeń ideowych, zawsze jest wychowaniem do jakichś wartości. To wartości, rozumiane jako to, co cenne $^{2}$, wyznaczają z jednej strony cele wychowania (stanowiąc ich źródła i uzasadnienie), z drugiej - kryteria oceny działań wychowawczych.

Dlatego też zasadnicze problemy i trudności związane $\mathrm{z}$ wychowaniem dotyczą nie metod, form i środków - jak mogłoby się wydawać na podstawie obserwacji praktyki pedagogicznej i podejmowanych na jej temat dyskusji, ale przede wszystkim źródeł, wyboru, porządkowania i wewnętrznej spójności przyjmowanych wartości, wokół których buduje się formalne i nieformalne procesy wychowawcze. Wskażmy kilka najtrudniejszych problemów w tym zakresie oraz powstających w ich wyniku dylematów.

Zanim je zarysujemy, zatrzymajmy się na znaczeniu sformułowania wychowanie do wartości. Obejmuje ono działania w dwóch zakresach. Pierwszy - szerszy, bardziej neutralny, dotyczy przygotowania człowieka do samodzielnego, świadomego funkcjonowania w świecie wartości (ich do-

2 Przyjmuję to skrótowe ujęcie wartości, podobnie jak m.in. W. Chudy. Por. W. Chudy, Pedagogia godności. Elementy etyki pedagogicznej, Lublin 2009. Zakłada ono zarówno istnienie wartości obiektywnych - jak i subiektywnych, wartości bezwzględnych i względnych, wartości wyższych i niższych. 
strzegania, wybierania, porządkowania, aktualizowania, realizowania, tworzenia). W tym zakresie, który można by określić edukacją aksjologiczna, celem jest kompetencja i dojrzałość aksjologiczna. Drugi - węższy obejmuje kształcenie w człowieku rozumienia i gotowości przyjęcia wartości pożądanych z perspektywy wprowadzanego programu wychowawczego oraz motywacji do życia tymi wartościami. Celem tego zakresu wychowania do wartości jest przygotowanie i umotywowanie wychowanka do świadomego i dobrowolnego wybierania uznanych za pożądane wartości, a także do ich hierarchizowania, realizowania, tworzenia w duchu przyjętego ideału wychowania (koncepcji człowieka, kierunku jego rozwoju, tworzących go i warunkujących jego rozwój cech)3.

\section{Współczesne dylematy wychowania do wartości}

Z jednej strony zasadność, z drugiej - możliwość wychowawczego wpływania na stosunek wychowanków do wartości stanowiły zawsze problem nieodłączny od działań pedagogicznych, ale współcześnie stał się to problem szczególnie newralgiczny, budzący gorące spory i polaryzujący środowiska pedagogiczne. Poważne kontrowersje wzbudza już sama zasadność wychowania do wartości, ponieważ powszechnie przyjęte traktowanie wartości jako preferencji - indywidualnych bądź grupowych - każe poddawać w wątpliwość sens wychowywania do tak zindywidualizowanej i zrelatywizowanej sfery życia. Ten krytyczny wobec orientowania wychowania na wartości sposób myślenia prowadzi do sceptycyzmu wobec wychowania w ogóle, szczególnie wobec realizowanych programowo celów wychowawczych wiążących się z pożądanymi cechami, postawami, zachowaniami. Zwolennicy, a wobec presji dominującego sposobu myślenia - obrońcy wychowania do wartości, podkreślają, że nie ma wychowania bez wartości, wychowania neutralnego aksjologicznie. Jeśli się odrzuci wartości, ze swej istoty wybierane w sposób świadomy, wolny, podmiotowy, działaniom pedagogicznym pozostaje manipulacja i przedmiotowe traktowanie człowieka, kształconego programowo jedynie w zakresie instrumentalnej sfery osobowości, zaś w sferze kierunkowej skazanego głównie na mechanizmy socjalizacyjne. Do tych argumentów trzeba dodać jeszcze jeden, że również odżegnujące się od wychowania działanie dydaktyczne jest zawsze jaką́ formą wychowania do wartości, odbywającego się poprzez określony dobór treści,

${ }^{3}$ Szerzej piszę na ten temat m.in. w książce Prawda, dobro i piękno w wychowaniu człowieka jako osoby, Katowice 2000, a także w tekście Wychowanie do wartości, w: M. Ryś (red.), Autorytet prawdy. Wychowanie dzieci i młodzieży, Warszawa 2006. 
form, metod, określony sposób budowania relacji i organizowania procesu dydaktycznego, motywowania uczniów do uczenia się.

Dyskusja o zasadności wychowania w ogóle, a wychowania do wartości w szczególności, ma dziś także głębokie korzenie w kryzysie wizji człowieka a w konsekwencji - braku antropologii uznającej wyraźną jego tożsamość, pożądany kierunek rozwoju i cele stanowiące podstawę sensu życia. Za brakiem antropologii określającej cele człowieka idzie brak wspólnych wartości duchowych jako języka budowania wspólnoty ludzkiej. Lukę tę zapełnia podzielanie wartości ekonomicznych - co cechuje dzisiejszy świat i co zaczyna stanowić szczególną religię ekonomiczną, dyktującą sposoby myślenia, kryteria oceny, zasady moralne i sens życia ${ }^{4}$. Istnieje niebezpieczeństwo, że edukacja włączy się w wychowanie do wartości ekonomicznych jako najważniejszych wartości współczesnego człowieka.

Podobnie jak zasadność, tak i możliwości wychowywania do wartości wzbudzają w kontekście działań pedagogicznych stale powracające spory. Przykładem ich aktualności może być dyskusja między dwiema współczesnymi przedstawicielkami holenderskiej filozofii edukacji - J. de Ruyter i F. Heyting - o roli ideału w edukacji i roli nauczycieli w przekazywaniu ideałów uczniom. Ideały są w tym kontekście rozumiane jako stany rzeczy, którym przypisuje się najwyższą wartość. Relacjonujący tę dyskusję Piotr Kostyło $^{5}$ streszcza istotę spornych stanowisk, ilustrując je znamiennymi cytatami z przywoływanych tekstów:

De Ruyter zakłada, że oferowanie ideałów jest jednym z podstawowych zadań nauczyciela i ma ono wpływ na kształtowanie charakteru moralnego uczniów. «Jest rzeczą oczywistą, że cele edukacyjne powinny obejmować idealne cechy charakteru moralnego i że dzieciom należy przekazywać ideały moralne, niezależnie od tego, jakie ogólne pojęcie idealnej osoby im przedstawiamy, czy to będzie na przykład osoba autonomiczna, osoba gorliwa religijnie czy osoba odnosząca sukcesy finansowe.» (de Ruyter, 2003, s. 476-477). Heyting wątpi w efektywność przekazywania ideałów uczniom przez nauczyciela. Twierdzi, że nauczyciel nie jest $\mathrm{w}$ stanie tego dokonać $\mathrm{z}$ tego względu, że proces kształtowania ideałów jest ekskluzywnie osobisty i dokonuje się w ukryciu ludzkiej świadomości, wrażliwości etycznej czy religijności. Nauczyciel może efektywnie prezentować uczniom cele edukacyjne, ale nie ideały: «Twierdzę, że

${ }^{4} \mathrm{Na}$ zjawisko to zwraca uwagę w swych tekstach Ch. Delsol, operując m.in. pojęciem „religii ekonomicznej”. Por. Ch. Delsol, Esej o człowieku późnej nowoczesności, Kraków 2003.

${ }^{5}$ Autor analizuje prezentowaną różnicę zdań w świetle poglądów W. Jamesa na temat ideałów i ich roli w edukacji. Por. P. Kostyło, Edukacja i ideały, w: T. Hejnicka-Bezwińska (red.), Pedagogika ogólna. Dyskursy o statusie naukowym i dydaktycznym, Bydgoszcz 2011. 
oferowanie ideałów dzieciom nie sprawia, że stają się one ideałami dla dzieci» (Heyting 2004, s. 246) .

Różnica prezentowanych poglądów dotyka jednego jeszcze zagadnienia, niezwykle istotnego w kontekście wychowania do wartości. Ze wspomnianej dyskusji wynikałoby, że jeśli można przekazywać ideały (najwyższe wartości), mogą one i powinny być zawarte w celach edukacji, co dotyczy szczególnie edukacji moralnej. Jeśli natomiast nie jest to możliwe, działanie edukacyjne zmierzające do realizacji określonych celów edukacyjnych nie może i nie powinno dotyczyć wartości i odwoływać się do nich. Teza ta budzi jednak wątpliwości. Cele edukacyjne jako takie podejmowane są ze względu na to, że opisywany nimi stan uważa się za jakoś cenny a więc wartościowy. Nawet jeśli programowo nie wskazuje się wartości, które uzasadniają wartościowość stanu pożądanego i określonego jako cel, nie znaczy to, że nie leżą one u podstaw podejmowanych decyzji. Mogą stanowić program ukryty danego działania edukacyjnego. Choć nie są formalnie deklarowane, jednakże wyznaczają cele, metody, formy i środki edukacji. Bez ich rozpoznania trudno jest wyjaśnić dobór zasadniczych elementów działania edukacyjnego czy systemu edukacji. Jeśli przez wychowanie rozumie się wszelkie, intencjonalne i nieintencjonalne oddziaływania kształtujące człowieka, czy nawet więcej - działania ukierunkowane na pożądany cel, to znaczy na jakiś ideał człowieka, a także na wywołanie w człowieku koniecznych na tej drodze zmian, u jego podstaw mogą leżeć bardzo różne wartości, wyznaczane przez poszczególnych wychowawców (głównie rodziców i nauczycieli), środowiska i instytucje wychowujące, wreszcie - przez społeczeństwo. W tej sytuacji pozostawałoby zgodzić się z W. Jamesem, którego teksty o ideałach w edukacji, pisane w duchu pragmatyzmu i pluralizmu, pozwalają wyodrębnić trzy możliwe strategie stosunku do przekazywania w toku edukacji ideałów (subiektywnych wartości najwyższych): przekazywanie ich w ramach edukowania elit społecznych, które następnie wprowadzą je w życie społeczne; pozostawienie ich całkowicie bez ingerencji z założeniem, że każdy ma prawo mieć własne wartości, które należy akceptować; bądź wreszcie poddać dobór wartości realizowanych w toku edukacji społecznym negocjacjom, z założeniem, że doprowadzą do decyzji legitymizowanych demokratyczną drogą do społecznego ładu, stanowiąc podstawę wychowania demokratycznego ${ }^{7}$.

${ }^{6}$ Tamże, s. 380. Autor P. Kostyło odsyła czytelnika do tekstów: F. Heyting, Beware of Ideale in Education, "Journal of Philosophy of Education" 2 (2004) i D. J. de Ruyter, The importance of Ideals in Education, "Journal of Philosophy of Education" 3 (2003).

7 P. Kostyło, dz. cyt., s. 392. 
Najczęściej, mówiąc o „wychowaniu do wartości”, mówi się i myśli o bliżej nieokreślonym działaniu, przybliżającym do wartości ogólnie „pozytywnych" - w znaczeniu wartości ogólnoludzkich, wyższych, duchowych, rzadziej - osobowych, a w kulturze chrześcijańskiej - chrześcijańskich. W dzisiejszej kulturze deklaratywnie akcentuje się także potrzebę wychowania do wartości społecznych i kulturowych, a milcząco zakłada się oczywistość potrzeby wychowywania do wartości zapisanych w prawach człowieka. Wartości uznawane ogólnie za pozytywne i w tym sensie uwzględniane w programach wychowawczych precyzowane są jednak bardzo rzadko, interpretuje się je raczej intuicyjnie a w konsekwencji - dosyć dowolnie.

Niezależnie od ogólnikowych deklaracji programowych, praktyka szeroko rozumianego wychowania pokazuje, że mamy dziś do czynienia z wychowaniem głównie do wartości pragmatycznych, użytecznych, materialnych, przyjemnościowych, czyli według tradycyjnej hierarchii - do wartości niższych. J. Rutkowiak i E. Potulicka w wielu swoich badaniach i tekstach zwracają uwagę, że edukacja zachodnia, w tym w coraz większym stopniu edukacja polska, orientują się na wartości dyktowane przez ogólnoświatowy system neoliberalny i narzucany przez ten system program edukacyjnego programu ekonomii korporacyjnej. Polega on na kształceniu nietwórczych producentów i bezkrytycznych konsumentów na potrzeby wolnego rynku. J. Rutkowiak, podzielając poglądy P. Bernardina ${ }^{8}$, pisze o tym modelu edukacji, iż „uchylając się od podejmowania problematyki wartości, nie eksponuje kwestii etyczno-duchowych jako treściowo odmiennych lub wysuwa je niewyraziście, a w praktyce kształcenia realizuje tzw. nauczanie niepoznawcze" . Autorka zwraca uwagę, że takie nauczanie nie tylko zubaża intelektualnie i utrudnia rozwój wrażliwości moralnej, ale wdraża głównie do adaptacji do aktualnej rzeczywistości.

W tym miejscu widoczna jest pierwsza trudność wiążąca się ze współczesnym wychowaniem do wartości i pierwszy obszar dylematów aksjologicznych: sprzeczność wartości stanowiących deklarowane i praktycznie realizowane cele wychowania zarówno formalnego, jak nieformalnego. Cele deklarowane - rozwijanie podmiotowości, postaw twórczych, krytycyzmu, odpowiedzialności za siebie, innych i świat, otwartości i postaw dialogowych wobec innych - szczególnie tych różniących się kulturowo - stanowią bardzo często jedynie ogólnikową, ,dekoracyjną" nadbudowę procesów kształcenia młodego pokolenia. Dzisiejsza edukacja jest bowiem w praktyce edukacją do skutecznego funkcjonowania we współczesnej cywilizacji,

${ }^{8}$ Por. P. Bernardin, Machiavel nauczycielem, Komorów 1997.

9 J. Rutkowiak, Nauczyciel $w$ dramacie wartości wychowawczych, w: E. Potulicka, J. Rutkowiak, Neoliberalne uwikłania edukacji, Kraków 2010, s. 239. 
do bezwzględnej konkurencji, bezkompromisowej, nierzadko prowadzonej kosztem innych, walki o sukces, o pozycję materialną, społeczną i towarzyską a przynajmniej do umiejętnego adaptowania się do zaistniałej sytuacji. Reguły pożądanego sukcesu, jego wskaźniki i kryteria jego oceny dyktowane są z zewnątrz, głównie przez mechanizmy rynkowe i modele producenta/ konsumenta wzmacniane wzorami kultury masowej. Szkoła, ale i rodzina, wychowując próbują godzić promowane kulturowo ideały człowieka twórczego, autonomicznego w działaniu, podmiotowo funkcjonującego w rzeczywistości, wrażliwego na los innych - wykluczonych, dyskryminowanych, skazanych przez mechanizmy globalizacji i agresywne interesy na całkowitą marginalizację aż do zagrożenia życia, z inwestowaniem w przyszłość dziecka zgodną z wzorami człowieka sukcesu, który może sobie pozwolić na korzystanie $\mathrm{z}$ wszelkich ofert rynkowych i chce $\mathrm{z}$ nich korzystać, traktując to jako przysługujące mu prawo realizowania siebie i „godnego życia”. Zarówno program szkół, jak funkcjonowanie nauczycieli nastawione są na godzenie wartości związanych z jednej strony z dobrem dziecka, pojmowanym jako jego wielostronny rozwój i kształcenie podmiotowości, także z ideową wizją roli nauczyciela i wychowawcy, z drugiej - z pragmatycznymi wartościami dotyczącymi dobra dziecka w systemie bezwzględnej społecznej konkurencji, dobra własnego dorosłych (komfortu życia rodziców, bezpieczeństwa zawodowego nauczycieli, satysfakcji materialnej jednych i drugich), wreszcie dobra szkoły (opinii opartej na liczbie laureatów konkursów i olimpiad, marką na rynku oświatowym, aprobatą władz oświatowych, satysfakcją sponsorów). Wartości edukacyjne teoretycznie oznaczają wartości prorozwojowe, służące rozwojowi podmiotowości, tożsamości, rozumienia rzeczywistości, konstruktywnego i twórczego w niej funkcjonowania, a praktycznie - wartości instrumentalne - kompetencje do pozytywnego zaliczania kolejnych sprawdzianów zewnętrznych, mierzących wyniki nauczania odnoszone do sztywnych standardów i przeciętnych możliwości. Sytuację dylematów aksjologicznych komplikują trudne do pogodzenia postulaty równoczesnego podnoszenia jakości kształcenia i obniżania jego kosztów, a więc konieczność godzenia wartości edukacyjnych z ekonomicznymi.

Widoczna niespójność funkcjonujących w wychowaniu wartości wywołuje pogłębiającą się z wiekiem dezorientację dzieci i młodzieży, nieufność wobec deklaracji i programów, poczucie uczestnictwa w fałszywej grze pozorów, cynizm i agresję wobec wszelkich perswazyjnych przekazów o wartościach. Dotyczy to w pierwszym rzędzie rodziny i szkoły, wobec których oczekiwania są największe a rozczarowania - najbardziej bolesne. Niespójność ta działa także destrukcyjnie na uczestniczących w wychowaniu dorosłych, tracących wiarę we własne kompetencje (co napędza rynek uniwersalnych poradników i specjalistów od planowania i realizowania ży- 
cia innych), w sens pracy nad wielostronnym rozwojem potencjału dziecka, niegwarantującym w miarę przewidywalnego sukcesu.

\section{Wychowawcza droga do wartości}

W wychowaniu do wartości ostatecznie chodzi o to, by przygotować i/ lub (zależnie od przyjętej koncepcji człowieka i jego wolności) doprowadzić wychowanka do uwewnętrznienia i dobrowolnego, świadomego uznania za własne wartości pożądanych wychowawczo, do ich realizowania w życiu.

Droga do tego celu prowadzi przez kilka etapów. Są to: odkrywanie wartości, ich przeżywanie, interioryzacja i internalizacja.

Odkrywanie wartości jest etapem ich poznawania i zrozumienia. Etap ten jest uwarunkowany możliwościami rozpoznania wartości przez ich nazwanie, a także zrozumienie ich sensu, oparte na rzetelnym wyjaśnieniu i pokazaniu wiarygodnych przykładów ich realizacji. Potrzebny jest więc język umożliwiający nazywanie wartości, wyjaśnianie, rozmawianie i myślenie o nich. Tu pojawia się kolejna trudność i kolejny krąg dylematów. W dzisiejszej praktyce wychowania unika się mówienia o wartościach, przede wszystkim o wartościach wyższych, rozmowy o nich, traktując je wyłącznie jako subiektywne, indywidualne bądź grupowe preferencje. U źródeł leży obawa przed oskarżeniami o indoktrynację, moralizowanie, ale także przed wyśmianiem podejmowania tematyki pozytywnych wartości jako silenia się na patetyczność czy naiwny idealizm. Nawet edukacja literacka nie uczy ani myślenia o wartościach, wyrażania ocen, sądów wartościujących, ani ich wymieniania i konfrontowania $\mathrm{z}$ innymi, co w dziejach kultury działo się poprzez pogłębioną lekturę pięknych, głębokich tekstów. Czy więc mówić o wartościach, narażając się na trudne pytania, konieczność obrony uznawanych wartości przed agresywnymi atakami, ukazywanie istoty otwartości, tolerancji, dialogu z inaczej myślącymi, starając się równocześnie o wrażliwą formę przekazu dostosowaną do jego materii, czy raczej wycofać się na grunt kontaktu głównie dydaktycznego, organizacyjnego, formalnego, traktującego wartości jako ściśle prywatną sferę uczestników procesu edukacyjnego.

Zrozumienie wartości wymaga, poza nazwaniem, również ich bezpośredniego poznania w kontakcie z realizującym je człowiekiem a także z wytworami stanowiącymi ich nośniki. Potrzebna jest więc możliwość zetknięcia się z wzorami osobowymi, z wartościowymi przedmiotami i działaniami, potrzebne są wartościowe przykłady. Ten wymóg pogłębia sygnalizowaną wyżej trudność. Wychowanie do wartości musi prowadzić przez poznawanie 
konkretnych, niosących te wartości przykładów osób, dzieł i działań ${ }^{10}$. Można by zapytać, czy dziś praktyka wychowawcza rezygnuje programowo z tej sfery działań, czy też nie jest w stanie wskazać wiarygodnych wartościowych wzorów i przykładów? Niejasna postawa wobec ideałów wychowawczych z jednej strony (raczej krytyczna i nieufna) - spotyka się z praktyką przyjmowania patronów szkół i placówek edukacyjnych, a tym samym z potrzebą opracowywania i realizowania programów, które z wyboru danej postaci wyprowadzałyby możliwości pozytywnego oddziaływania. Z drugiej strony działanie wychowawcze staje wobec wpływu kultury masowej podsuwającej i promującej postaci idoli, przejmujących w ogromnym stopniu wpływ na młode pokolenie. Czy środowiska wychowawcze mają przemyślaną, wypracowaną strategię $\mathrm{w}$ tym zakresie? Czy rezygnacja $\mathrm{z}$ ukazywania ideałów wychowania, realizowanych w życiu przez konkretne osoby, oznacza uwolnienie wychowanków od wpływu jakichkolwiek wzorców, uważanych za zagrożenie wolności późniejszych własnych wyborów?

Drugim etapem nabywania wartości jest ich przeżywanie. Pogłębia ono i wzmacnia na drodze budzenia emocji zainteresowanie danymi wartościami, nasyca je emocjonalną treścią, sprawia, że przyciągają lub odpychają. Wychowawca musi więc aranżować wokół przekazywanych wartości sytuacje sprzyjające ich przeżywaniu. Służą temu w szczególny sposób sztuka w całym bogactwie dziedzin, gatunków i środków, wszelkie formy obrzędowości, celebrowania, świętowania, kontaktów z ekspresyjnymi formami przekazu. Rodzą się pytania - czy dzisiejsze środowiska wychowawcze wykazują wystarczające zrozumienie i troskę o ten wymiar oddziaływań? Czy jest w nich miejsce na głębsze, bogatsze przeżycia, czy raczej odwołują się głównie do przeżyć zabawowych, rozrywkowych, angażujących poprzez najprostsze formy aktywności, stymulujących najbardziej podstawowe emocje - strach, złość, przyjemność itp.? Przeżycia te, odwołujące się do potrzeb niższych, wzmacniają tym samym wartości niższe, niezależnie od intencji wychowawczej. Jest to częste niebezpieczeństwo wychowania do wartości. Metoda i środki nie są w tej dziedzinie obojętne. Mogą osłabić a nawet zniszczyć zasadniczy sens wartości, o które chodzi, eksponując i tym samym wzmacniając wartości inne niż zakładane (metody i środki oparte na wartościach niższych nie mogą wzmacniać wartości wyższych a cel nie uświęca środków). Pojawia się więc kolejna sprzeczność: z jednej strony świadomość roli kultury i podstawy jej przeżywania - bezinteresowności, funkcji sztuki w rozwijaniu sfery przeżyciowej, roli celebrowania ważnych wartości, z dru-

${ }^{10}$ Wpływ kontaktu z osobami realizującymi wartości na ich odkrywanie analizuję w książce $O$ roli przykładu, wzoru, autorytetu i mistrza $w$ wychowaniu osobowym, Toruń 2007. 
giej - wykorzystywanie sytuacji świętowania, celebrowania instrumentalnie do pragmatycznych celów (reguły wydarzeń kulturalnych dyktowane przez sponsorów), sytuacje nasycone emocjonalnie wykorzystywane do bieżącej gry politycznej, sztuka traktowana jako luksusowy dodatek do codziennego życia (lekceważenie roli edukacji kulturalnej, w tym - estetycznej).

Etap trzeci to uwewnętrznianie - interioryzacja. Wymaga stwarzania sytuacji możliwie systematycznego powtarzania pożądanych doświadczeń, które angażują w bezpośrednie realizowanie pożądanej wartości. Praktykowanie określonych wartości, ćwiczenie związanych z nimi zachowań, opanowywanie sprawności ułatwiających kontakt z nimi - to warunki pozytywnych efektów tego etapu dojrzewania do wartości. I znów nasuwa się pytanie: czy dzisiejsza praktyka wychowawcza szuka takich pozytywnych wartościowo doświadczeń, żeby zachęcać do nich wychowanków, stwarzać sprzyjające okoliczności ich praktykowania, aranżować sytuacje motywujące do systematycznego realizowania podjętych działań, stawiać zadania wymagające podejmowania takich doświadczeń? To zadanie wymaga poświęcania im czasu, towarzyszenia przez dorosłych w utrwalanych jako pożądane działaniach, ich inicjowania i wspomagania. W tym kontekście nastawienie szkoły głównie na dydaktykę a rodziny - na zdobywanie środków materialnych powoduje nieuniknioną sprzeczność z wymogami interioryzacji wartości.

Ostatni etap to internalizacja wartości - uznanie za własne i życie zgodne $\mathrm{z}$ uznanymi i przyjętymi wartościami. $\mathrm{W}$ tym etapie niezbędna jest praca nad pogłębianiem postaw warunkujących bezinteresowność, dobrowolność, pełną świadomość wyborów aksjologicznych. Najważniejsze z tych postaw to postawa wierności uznanym wartościom, szacunku wobec nich, podziwu, zachwytu, odpowiedzialności za ich obecność i realizację w świecie. Również tu obserwacje nie są zbyt optymistyczne. Postawy te bardzo trudno byłoby znaleźć zarówno w programach, jak w praktyce współczesnych działań wychowawczych, prowadzonych przez środowiska odpowiedzialne za tę sferę życia. Powraca w rodzinie i w szkole sprzeczność promowanych kulturowo wartości i ich hierarchii, w których bezinteresowność, wierność, zachwyt i podziw nad wartościami wyższymi są na ogół eliminowane i kompromitowane jako nieużyteczne, „nieżyciowe”.

W przeciwieństwie do najważniejszych środowisk wychowawczych masowe media metodycznie kontrolują świat wartości swoich odbiorców, w tym - dzieci i młodzieży, by go modelować na swoje potrzeby. Oddziałują programowo na wszystkie etapy nabywania wartości, ucząc pożądanego języka wartościowań, podsuwając wzory osobowe, manipulując przeżyciami, ćwicząc poprzez poszerzającą się interaktywność pożądane zachowania i postawy. Można powiedzieć, że media są dziś najbardziej konsekwentnym 
podmiotem wychowującym do pożądanych przez siebie wartości - wartości składających się na model bezkrytycznego konsumenta.

\section{Wychowanie do wartości w świetle personalizmu chrześcijańskiego}

Od dylematów aksjologicznych nie jest wolna również praktyka wychowania do wartości osobowych i chrześcijańskich, choć przyjęta tu wyraźna antropologia (personalizm etyczny ${ }^{11}$ i jego szczególny zakres - personalizm chrześcijański) oraz stosunek do wartości, zakładający różne ich rodzaje, sposoby istnienia i poznawania, daje podstawy do rozstrzygania dylematów wpisanych w naturę sytuacji pedagogicznych. Najważniejszą, obiektywną wartością jest $\mathrm{w}$ tym ujęciu godność człowieka, wiążące się z nią wolność i rozumność (W. Chudy podkreśla w tym kontekście także rolę cielesności jako wymiaru osoby ludzkiej ${ }^{12}$ ), wpisane w człowieczeństwo kierunki dążenia - prawda, dobro, piękno i świętość, wartość pozwalająca zrealizować człowieczeństwo - miłość, wreszcie wartości stanowiące warunki rozwoju osoby i jej służby wspólnocie - życie, pokój, sprawiedliwość, solidarność, rozwój, wartości ekologiczne a także inne wartości służebne wobec głównych wartości osobowych.

Jeśli cel wychowania jest zgodny z celem i powołaniem człowieka - budowaniem w człowieku człowieczeństwa, przygotowywaniem go do bycia w pełni realizującą się osobą ludzką - wychowanie oznacza wychowanie do wartości „budujących duchowy wymiar ludzkiej rzeczywistości” - jak określał je bł. Jan Paweł II, zwracając równocześnie uwagę na to, że człowiek myślący osobowo nie może rozdzielać wartości osobistych i wartości społecznych $^{13}$. Wychowanie osoby ludzkiej jest wychowaniem do wartości, jakimi są w pierwszym rzędzie godność i powołanie człowieka. Powołaniem tym jest poszukiwanie prawdy, dążenie do odkrytego $\mathrm{w}$ prawdzie dobra, kontemplowanie piękna i tworzenie warunków do jego ujawniania się $\mathrm{w}$ świecie. Jest to powołanie do miłości jako bycia bezinteresownym darem dla drugiego. Wychowanie do wartości osobowych powinno uwzględniać w programach i ich realizacji zasadnicze etapy dojrzewania do wartości, ich przyswajania, dobrowolnego wybierania, wiernego realizowania. Nie można

${ }^{11} \mathrm{~W}$ personalizmie etycznym osoba jest podmiotem moralnym odpowiedzialnym za siebie, innych i świat, samostanowiącym o sobie i kierującym się prawdą o bezwarunkowej, obiektywnej wartości człowieczeństwa - godności ludzkiej. Przedstawicielami personalizmu w polskiej filozofii są: K. Wojtyła, A. Rodziński, A. Półtawski, A. Szostek, T. Styczeń.

${ }^{12}$ W. Chudy, dz. cyt., s.42.

13 Por. Orędzie Jana Pawła II na XVIII Światowy Dzień Pokoju, z dn. 8.12.1984. 
zakładać, że osobowe dojrzewanie dokonuje się niejako automatycznie, jedynie w wyniku dobrej woli i pozytywnych intencji środowiska wychowawczego, ogólnie akceptującego, nawet zapisującego w dokumentach programowych wartości osobowe, nie wprowadzając ich ani w szczegółowe treści, ani w metody i formy działania edukacyjnego.

Świat wartości chrześcijańskich nadaje wartościom osobowym pełne uzasadnienie, pokazuje ich źródła i sens. Bł. Jan Paweł II w przywoływanym wyżej Orędziu na XVIII Światowy Dzień Pokoju z 1984 roku określił życie człowieka jako odkrywanie wartości odzwierciedlających godność i powołanie człowieka jako osoby ludzkiej, sprzyjających życiu i budujących świat pokoju i sprawiedliwości. W tym ważnym wychowawczo tekście, adresowanym głównie do młodzieży, znajdujemy niezwykle istotny dla wychowania w duchu chrześcijańskim kierunek działania. Jest nim uczenie szukania prawdy, uświadamianie podstawowych dla każdego człowieka pytań, zachęcanie do ich podjęcia, wnikliwego rozważenia, stawiania uczciwych odpowiedzi. Wspomniane Orędzie zostało zbudowane wokół dwu najważniejszych dla życia człowieka pytań, równocześnie pytań o najważniejsze dla człowieka wartości. Jan Paweł II zapytał w tym tekście ludzi współczesnych, szczególnie młodych: jakie jest Wasze pojęcie człowieka? i kim jest Wasz Bóg?

Wskazane przez Jana Pawła II cechy - podstawowe wartości człowieka jako osoby - mogą być zrozumiane przez wychowanków, jeśli będą się opierały w pierwszym rzędzie na codziennym kontakcie z osobowymi wzorami - świadkami tych wartości. Stopniowo, wraz z rozwojem możliwości intelektualnych wychowanków, coraz większego znaczenia nabiera potrzeba rzetelnej rozmowy opartej na poważnych pytaniach, na uczeniu myślenia o sobie i świecie, potrzeba odwoływania się do wrażliwości ideowej młodych ludzi. Poważnie rozmawiać, szczególnie o wartościach, może ktoś, kto jest wiarygodny w swoich postawach. Potrzebne jest jednak nie tylko wspólne przeżywanie i wymiana myśli, szukanie prawdy, ale wspólne działanie na rzecz dobra drugiej osoby, dobra wspólnego jako możliwości realizowania dobra każdego członka danej wspólnoty. Zadaniem wychowawcy wychowującego do realizacji wartości osobowych jest tworzenie sytuacji indywidualnego i wspólnego działania na rzecz dobra i osobisty udział w tych sytuacjach. To on powinien być wzorem i nauczycielem postaw wierności, szacunku, podziwu, zachwytu wartościami, odpowiedzialności za ich obecność w świecie. W tym kontekście wyzwaniem staje się decyzja, czy można i należy godzić w pracy wychowawczej realizację wartości osobowych i wartości „konsumpcyjnych”, a jeśli tak, jakie warunki muszą być spełnione, jakie zasady respektowane, by dylemat ten nie zmienił się w kolejną milcząco akceptowaną sprzeczność edukacyjną. By chrześcijańscy nauczyciele i wychowawcy nie adaptowali się zbyt łatwo do rzeczywistości szkolnej służącej 
często innym niż osobowe wartościom, by nie przyjmowali milcząco reguł i rozwiązań sprzecznych z kształtowaniem osobowego człowieczeństwa zarówno w wychowankach, jak w sobie, nie akceptowali przyjętych w środowiskach edukacyjnych i wszędzie, gdzie się znajdą, antyosobowych relacji społecznych, nierespektujących godności ludzkiej i obowiązku szacunku wobec każdego człowieka. Wydaje się to trudnym wyzwaniem dla dzisiejszych wychowawców, których - jak przekonywał w swoim przemówieniu w siedzibie UNESCO w 1980 roku bł. Jan Paweł II - powinny cechować dobroć, mądrość i wiara.

W wychowaniu religijnym, tu - chrześcijańskim, wartości wyrastają z prawdy o Bogu i człowieku. Prawda ta musi być wytrwale zdobywana, wspólnie z wychowankami poszukiwana w trudnym wysiłku, niezamienianym w zabawę, sztuczne ułatwiania i przyjemności. Jest prawdą decydującą o znalezieniu sensu życia i wytrwaniu w dążeniu do świętości. Nie da się tych celów wprowadzać i realizować poprzez „chwilowo” łatwiejsze, prostsze, przyjemniejsze czy bardziej atrakcyjne w świetle modnych postulatów dydaktycznych, mających zwiększać motywację do uczenia się. Można i trzeba pokazywać radość dzielenia się chrześcijańską Dobrą Nowiną i racjami nadziei, radością z bycia z ludźmi i dla ludzi. Można i trzeba szukać form kontaktu i przekazu bliskich współczesnemu młodemu pokoleniu, ale trzeba równocześnie wyraźnie oznaczać sferę sacrum, bronić jej wartości przed rozmywaniem, przed środkami fałszującymi jej istotę i charakter, nawet jeśli są marketingowo sprawdzone. Trzeba nazywać i ukazywać wartości prawdy, dobra, piękna, godności ludzkiej, świętości, mówić młodym ludziom i pokazywać wielkość najwyższych wartości wyznaczających drogę do celu człowieka. Osoby podejmujące się wychowania religijnego, przyjmujące na siebie odpowiedzialność za tę misję i powołanie, są niezastępowalnym czynnikiem powodzenia procesu wychowania do wartości religijnych. Ich postawa, kompetencja, stosunek do ludzi i świadectwo życia są dla wychowanków podstawowym obszarem weryfikacji wskazywanych im wartości. Nie ma tu działań i zachowań obojętnych. Każdy z wychowawców staje się z momentem przyjęcia tej roli i powołania rzecznikiem wartości, które chce ukazać wychowankom jako program życia. Odpowiedzialność za wychowanie do wartości jest tu wyjątkowa. Dlatego też wyjątkowa musi być wrażliwość na potencjalne sprzeczności między deklarowaną rolą a dostosowywaniem się do funkcjonujących w kulturze konsumpcyjnej, w spragmatyzowanym, zmaterializowanym społeczeństwie wzorów życia, postępowania i działania. Dotyczy to również praktyki edukacyjnej, włącznie z praktyką edukacji religijnej.

Żeby uniknąć niebezpieczeństwa powierzchownie, bezrefleksyjnie rozstrzyganych dylematów aksjologicznych, a jak to się dzieje częściej - ich 
niedostrzegania i niedoceniania ich roli w wychowaniu do wartości, należałoby w wychowaniu wrócić do jasnego deklarowania wartości, jakim działanie to chce służyć i służy. Inaczej grozi nam pogłębiająca się alienacja wychowania. Oznacza ona, jak mówił Jan Paweł II we wspomnianym przemówieniu w UNESCO w 1980 roku, iż zamiast wychowywać człowieka do tego, by bardziej był, przyzwyczaja się go do bycia przedmiotem manipulacji i naucza życia jako manipulacji samym sobą. To ostrzeżenie nabiera dziś alarmującej aktualności.

\section{Zamiast konkluzji}

Podejmując te rozważania, sięgnęłam do swojego tekstu Dylematy wspótczesnego wychowania sprzed 20 lat $^{14}$, zastanawiając się, w jakim stopniu wychowawcze dylematy aksjologiczne, o których pisałam w 1991 roku, zostały rozwiązane bądź rozwiązały się same ze względu na przemiany społeczne, kulturowe, upływ czasu, a przede wszystkim zmiany w edukacji. Wśród nich podkreślałam wtedy brak decyzji dotyczących tego, jakim człowiekiem ma być wychowanek XXI wieku, jakie wartości chcielibyśmy, żeby samodzielnie, w sposób wolny i bezinteresowny dostrzegał, wybierał, uznawał, jakim był gotów służyć, jakie chciał realizować i tworzyć. Dylematy aksjologiczne zawsze będą towarzyszyły działaniom pedagogicznym, w których jedni - sami funkcjonujący w świecie określonych wartości - oddziałują na drugich, wpływając na to, co ci uznają i będą uznawać za cenne. Jest to najbardziej wrażliwa sfera działań pedagogicznych, w tym - przede wszystkim edukacyjnych. Jednak pozostawienie jej biegowi wypadków, przypadkom, doraźnej socjalizacji, podważa sens edukacji jako szeroko pojętego wychowania. Dlatego stwierdzenie, że dylematy te nie tylko nie zostały rozwiązane ale pogłębiają się, wywołując między innymi wzrost społecznej nieufności i krytyki wobec systemów edukacyjnych, a także rezygnację z jasnych, konsekwentnych działań wychowawczych, może budzić poważny niepokój. Nie tylko z perspektywy wychowania opartego na personalizmie etycznym i chrześcijańskim, ale z perspektywy humanizacji wychowania realizowanego $\mathrm{w}$ ramach edukacji pojawiają się nowe zagrożenia. Jest to presja modeli edukacyjnych realizujących praktycznie wychowanie do wartości utylitarnych, pragmatycznych, konsumpcyjnych, osłabiających szanse na kształcenie podmiotowości wychowanków, ich wolnego, świadomego, autonomicznego funkcjonowania w komplikującej się rzeczywistości. Edu-

14 K. Olbrycht, Dylematy współczesnego wychowania, „Znak” 9 (1991), s. 40-45; tenże, Wychowanie na rozdrożu (dyskusja panelowa), „Znak” 9 (1991), s. 46-61. 
kacja coraz bardziej koncentruje się na sprawnościach przydatnych w dynamicznie rozwijającej się cywilizacji, spychając na dalszy plan rozwój tych wymiarów osobowości, które decydują o sposobach wykorzystywania zdobytych sprawności. Nie można nie zauważać efektów braku zainteresowania wychowaniem, efektów potwierdzanych wynikami badań socjologicznych deficytu szacunku (por. między innymi badania socjologa kultury T. Szlendaka), bezwzględności w walce o sukces, lęku i agresji towarzyszących młodym ludziom od najwcześniejszego wieku. Pogłębianie się tego zjawiska nie powinno być jedynie groźną diagnozą, ale przede wszystkim wyzwaniem dla współczesnych nauk o wychowaniu, dla teoretyków i praktyków edukacji, dla podmiotów decydujących o rozwiązaniach instytucjonalnych i o tematach społecznej debaty.

\section{Education in Values - in the Centre of Axiological Dilemmas of the Contemporary Education (Summary)}

The author presents an argument that education in values is in the centre of axiological dilemmas of the contemporary education. She begins with introducing the main meanings of the term education and explaining how education in values is understood. The second part of the article consists of an analysis of contemporary dilemmas associated with education in values, especially how difficult it is to reconcile educating and upbringing in pragmatic and consumer values with higher, pro-development values. The next part discusses the educational path of assimilating values (preparation for discovery, reliving, interiorization, internalization). Finally, the text points out the dilemmas associated with education in personal values, in the light of Christian education. 